\title{
TOURISM GOVERNANCE: BUMDES AS THE SPIRIT OF COMMUNITY ECONOMIC EMPOWERMENT
}

\author{
Mayarni, Hasim As'ari and Adianto \\ Departement Public Administration, Faculty of Social Sciences, Riau University. \\ E-mail: mayarni@lecturer.unri.ac.id, hasimasari@lecturer.unri.ac.id, adianto@lecturer.unri.ac.id
}

\begin{abstract}
This study aims to determine the development of the Napangga Lake tourist attraction in Kepenghuluan Tanjung Medan, Rokan Hilir Regency, which greatly contributes to village-owned enterprises in empowering the community's economy. Lake Napangga is a new destination located in the Rokan Hilir area and has very promising tourism potential, so it must be managed professionally and have an economic impact on the local community. Therefore, village-owned enterprises must be able to become a spirit in developing this lake tourism object in order to empower the economy of the village community. This research uses a qualitative approach with a case study method, where data collection is done by observation and interviews. After the data and information are obtained, it will be analyzed in depth with data triangulation validity test. The results of this study found that the development of the Lake Napangga tourist attraction has not run optimally by the Bumdes in empowering the community's economy. This is due to the inconsistency in the number of tourists visiting Lake Napangga, because this tour is still seasonal. Strategies are needed to make economic empowerment for the community in order to increase income and improve the quality of life of the surrounding community.
\end{abstract}

Keywords: Tourism Governance; Bumdes; Community Economic Empowerment

\section{TATA KELOLA PARIWISATA: BUMDES SEBAGAI SPIRIT PEMBERDAYAAN EKONOMI MASYARAKAT}

\begin{abstract}
ABSTRAK. Penelitian ini bertujuan untuk mengetahui pengembangan objek wisata Danau Napangga di Kepenghuluan Tanjung Medan Kabupaten Rokan Hilir yang sangat memberikan kontribusi bagi Badan usaha milik desa dalam memberdayakan ekonomi masyarakat. Danau Napangga merupakan destinasi baru yang terletak di wilayah Rokan Hilir dan memiliki potensi pariwisata yang sangat menjanjikan, sehingga wajib dikelola dengan profesional dan memberikan dampak secara ekonomi bagi masyarakat setempat. Oleh karenanya, Badan usaha milik desa harus dapat menjadi spirit dalam mengembangkan objek wisata danau tersebut guna memberdayakan ekonomi masyarakat desa. Penelitian ini menggunakan pendekatan kualitatif dengan metode studi kasus, yang pengumpulan datanya dilakukan dengan observasi dan wawancara. Setelah data dan informasi diperoleh maka di analisis secara mendalam dengan teknik triangulasi data. Hasil penelitian menemukan bahwa pengembangan objek wisata Danau Napangga belum berjalan secara maksimal yang dilakukan oleh pihak Bumdes dalam memberdayakan ekonomi masyarakat. Hal ini dikarenakan belum konsistenya jumlah wisatawan yang berkunjung ke Danau Napangga, sebab wisata ini masih bersifat musimam. Strategi yang disarankan untuk membuat pemberdayaan ekonomi bagi masyarakat guna meningkatkan pendapatan dan meningkatkan taraf hidup kesejahteraan masyarakat sekitar.
\end{abstract}

Kata kunci: Tata Kelola Pariwisata; Bumdes; Pemberdayaan Ekonomi Masyarakat

\section{INTRODUCTION}

Napangga Lake is a lake that lies in the administrative area of Kepenghuluan Tanjung Medan, Rokan Hilir Regency, Riau Province. This lake has an area of \pm 2996 hectares and is one of the largest lakes in the Rokan Hilir Regency area. Lake Napangga has such beautiful tourism potential, such as the beautiful natural scenery around the lake area and the flat and clear water surface which adds to the beauty of the lake to be seen by the eye. This potential makes Lake Napangga one of the prima donna tourist destinations for the surrounding community, both the people of Rokan Hilir Regency.

The tourism potential of Lake Napangga is one of the reasons for the village government or Kepenghuluan Tanjung Medan to manage and develop it into one of the leading tourist destinations in Rokan Hilir Regency. The development and management of Lake Napangga tourism is handed over to BUMDes in Kepenghuluan Tanjung Medan.

BUMDes stands for Village-Owned Enterprises. According to (Ali, Sutarna, Abdullah, Kamaluddin,
\& Mas'ad, 2019) Village-owned enterprises exist as economic institutions village is one of the village programs as a means of increasing Village Original Income (PADes).

Tanjung Medan Village has a BUMDes called Cahaya Napangga and has taken over the development of Lake Nanpangga tourism from 2016 until now. Before the development was given to BUMDes, the management of Lake Napangga was carried out by the village community independently, but the management was not optimal. This is evidenced by the low number of tourist visits made by the community, even those visiting are only local villagers or neighboring.

However, after the management was handed over to BUMDes Kepenghuluan Tanjung Medan, BUMDes gradually began to improve the various tourist facilities provided on Lake Napangga. The hope is that the improvement of tourist facilities carried out will attract potential visitors to the Lake Napangga tourist destination. So that later it will have an impact on the economic empowerment of rural communities involved in the development of the Lake Napangga tourist destination under BUMDes. 
The development of Lake Napangga tourism destinations carried out by BUMDes, focuses on providing tourist facilities around Lake Napangga that can be enjoyed by potential visitors. The provision of tourist facilities carried out by BUMDes includes: visitor huts, toilets, prayer rooms, entertainment stages, lake cruising routes, water vehicles, photo spots and so on. BUMDes efforts to provide this tourist facility to attract potential visitors who will come to Lake Napangga. The development of tourist destinations is not enough to be done by providing physical facilities, of course it needs to be supported by non-physical developments as well. The non-physical development was carried out as a breakthrough that was chosen to attract potential visitors who would like to visit Lake Napangga. In this case event routinely at tourist destination locations, including Christmas and New Year events, Eid al-Fitr events, the Enchantment of Lake Napangga event, Karauke Competition, Gymnastics Competition and others. This event or activity is carried out aimed at increasing the number of tourist visits on Lake Napangga, so that it can have a positive effect on the development of rural communities, especially in the socio-economic field.

The existence of events held by the BUMDes turned out to have a positive impact on increasing the number of visitors to the Lake Napangga tourist destination. The increase in the number of visitors that occurs has an effect on increasing revenue for the management of Lake Napangga tourist destinations, through ticket sales and rental of tourist facilities provided on Lake Napangga. The increase in revenue for the management of Lake Napangga tourism destinations that was obtained by BUMDes Cahaya Napangga, turned out to have an impact on the people in Kepenghuluan Tanjung Medan. Village communities also experience income by participating in selling culinary delights and renting tourist facilities that have not been provided by the BUMDes, such as swimming tires, mats, swimsuit and others. The positive correlation that occurs between the development of Lake Napangga tourist destinations by BUMDes on the economic empowerment of rural communities must be maintained and developed. Therefore, this research formulates a problem: how does the development of the Napangga Lake tourist destination by BUMDes have an impact on the economic empowerment of rural communities.

Village-owned enterprises (BUMDes) are regulated in Law No. 6 of 2014 concerning the Villagein Article 87 paragraph (1) which reads: "Villages can establish VillageOwned Enterprises called BUMDes”. Paragraph (2) which reads: "BUMDesa is managed with a spirit of kinship and mutual cooperation," and paragraph (3) which reads, "BUMDesa can carry out business in the economic sector and / or public services in accordance with the provisions of laws and regulations". Then it is also regulated in the PDTT Permendesa Number 4 of 2015 concerning the Establishment, Management and Management, and the dissolution of Village-Owned Enterprises.

Village-owned enterprises (BUMDes) are an instrument of local economic empowerment with various types of businesses according to the potential of the village. The development of this potential has the aim of improving the economic welfare of villagers through economic business development. Besides that, the existence of BUMDes also brings impact on increasing the source of village income (PAD) which allows the village to be able to carry out a development and also to increase welfare more optimally. BUMDes is actually a social institution that sides with the interests of the community through its contribution as a provider of social services. However, BUMDes is also a commercial institution where BUMDes aims to seek profit through the sale of goods or services intended for the community.

BUMDes as a legal entity, was formed based on the applicable laws and regulations, and in accordance with the rules that apply in the village. Villages can establish Village-Owned Enterprises (BUMDes) according to the needs and potential of the village. In accordance with these regulations, the formation of BUMDes is based on the needs and potential of the village, with the aim of improving the welfare of the community. this is in line with the opinion (Kushartono, 2016) that BUMDes has a goal to improve the management of village potential Human and natural resources according to the needs of each village.

The presence of this BUMDes is expected that the village will become more independent and the community will be more prosperous. BUMDEs as a legal institution in developing businesses and the economy of local communities (villages) are expected to produce local superior products that can become a positive image in free market competition (MEA). One thing that must be considered is with regard to the expansion of the local product market through BUMDes by considering the following: 1) Building a special marketing center and outlet for BUMDes products; 2) Formulating regulations that require modern markets (such as: Giant, Indomaret, Alfamart, Hypermart etc.) to participate in marketing BUMDes products; and 3) Implementing a linkage strategy between BUMDes that produces intermediate raw materials and industries engaged in the downstream sector. So that the picture above is that the village has extraordinary resources, will be unable to compete if they cannot create the welfare of their people in the era of free competition which requires creative efforts in developing their social capital. Business development and the economy of rural communities are important to pay attention to, because increased competitiveness will drive economic growth, and the development and existence of villages as the lowest regional unit will have a positive impact nationally in facing free market competition.

Tourism is defined as a temporary journey from one place to another, carried out by individuals or groups as an 
effort to achieve balance or harmony with the environment to achieve happiness in the social, cultural, natural and scientific dimensions. According to (Sidiq, 2007) tourism is an activity or activity that is carried out for a while in order to broaden the insight into the social field, the behavior system of the human being itself with various encouragement of interests according to different cultures related to pleasure efforts, including object entrepreneurs. and tourist attraction and other businesses related in that field.

Jaelani (2018) said that tourism is a series of efforts carried out by the government, private sector, and society to improve, maintain or build, both quantitatively and qualitatively, of the creation of God, human beings, living systems, cultural arts and places or circumstances. nature that has an attraction to be visited or enjoyed by tourists. Several components of tourism products, including:

1. Tourist destination attractions

2. Facilities available

3. Accessibility and tourist destinations.

Prasetya \& Rani (2014) explains that tourism development as an ideal industry must be based on the following four basic principles:

a. Ecological sustainability, namely that tourism development must guarantee the creation of maintenance and protection of natural resources that attract tourism, such as the marine environment, forests, beaches, lakes and rivers.

b. The continuity of social and cultural life, namely that tourism development must be able to increase the role of the community in monitoring the order of life through the value system adopted by the local community as the identity of the community.

c. Economic sustainability, namely that tourism development must be able to create job opportunities for all parties to be involved in economic activities through a healthy and competitive economic system.

d. Improve and enhance the quality of life of local communities by providing opportunities for them to be protected in tourism development.

Furthermore, Mcinteyre (1993) can say that a destination will carry out tourism development if there are already tourism activities, to be able to increase its tourism potential, what needs to be done is to plan tourism development so that it can be better than before, three main principles in tourism development are:

1) Ecological sustainability, namely ensuring that the development carried out is in accordance with biological ecological processes, and the diversity of existing ecological resources.

2) Social and cultural sustainability, namely ensuring that the development carried out has a positive impact on the lives of the surrounding community and is in accordance with the culture and values that apply to the community.
3) Economic sustainability, namely ensuring that the development carried out is economically efficient and that the resources used can survive for future needs.

The purpose of this study is to find out how tourism development contributes to village-owned enterprises (BUMDes) to empower the economy of the surrounding community.

\section{METHODS}

This research is a qualitative research with a descriptive case study approach. The case study approach is a qualitative approach in which researchers explore real life, contemporary limited systems (cases) or various limited systems (various cases), through detailed and in-depth data collection involving multiple sources of information or multiple sources of information (e.g. observations, interviews, audiovisual materials). , documents and various reports). Then the researcher reported the case description and the theme of the case which was used as research material. Case study data can be obtained from all parties concerned in the research. Descriptive analysis is a method of examining the status of a group of people, a condition (Creswell,2017).

The informants in this study are as follows, consisting of key informants and complementary informants. The informants selected for the individuals are as follows: 1). The key informant is the BUMDes manager. 2). The complementary informants were the people in Kepenghuluan Tanjung Medan. Data collection was carried out in stages from observation, interviews and documentation with several informants who had been selected by researchers as sources in this study. Primary data obtained in the field through in-depth interviews and observations. Meanwhile, secondary data is obtained through available documentation or obtained from print media or websites. The instrument for obtaining primary data used interview guidelines which were prepared in order to extract the information needed to complete the research. According Afrizal (2016) This study uses data collection techniques as a case study research, where data is collected by revealing the phenomena that are the focus of the study. So this study also enriches the data by triangulating data sources by combining several data sources, namely in-depth interviews, secondary data analysis, website searches and news searches in print media on relevant topics. Then the data analysis of this research uses descriptive qualitative analysis techniques. where data is collected by revealing the phenomena that are the focus of the research. So this study also enriches the data by triangulating data sources by combining several data sources, namely in-depth interviews, secondary data analysis, website searches and news searches in print media on relevant topics. Then the data analysis of this 
research uses descriptive qualitative analysis techniques. where data is collected by revealing the phenomena that are the focus of the research. So this study also enriches the data by triangulating data sources by combining several data sources, namely in-depth interviews, secondary data analysis, website searches and news searches in print media on relevant topics. Then the data analysis of this research uses descriptive qualitative analysis techniques.

\section{RESULTS AND DISCUSSION}

Tourism development is needed in an effort to make Lake Napangga a tourist destination in Rokan Hilir Regency. This is because Lake Napangga has the potential to be sold or presented to every potential visitor who comes. These potentials include beautiful natural scenery, adequate facilities as a tourist attraction and public facilities that are starting to be provided for the convenience of prospective visitors. Tourism development on Lake Napangga was pioneered and managed by BUMDes Cahaya Napangga Kepenghuluan Tanjung Medan. The concern and involvement of BUMDes Cahaya Napangga in the development of Lake Napangga tourism aims to develop the potential in the village and provide a spirit for the economy of the village community through empowering tourism management.

BUMDes Cahaya Napangga as the manager of the Napangga Lake tourist destination in recent years has tried to make development efforts in various ways, both physical and non-physical. The tourism development carried out physically by BUMDes Cahaya Napangga, includes providing facilities and infrastructure in tourist areas such as: prayer rooms, toilets, lodges for tourists to rest, areas for walking, photo spots and entertainment stages for visitors.

The development of tourism facilities and infrastructure carried out by BUMDes Cahaya Napangga basically aims to promote Lake Napangga tourist destinations to all people of Rokan Hilir Regency, Riau Province, National and International. This innovative effort was also carried out in order to empower the economy of the people in Kepenghuluan Tanjung Medan and strengthen business units managed by BUMDes Cahaya Napangga. Because the BUMDes Cahaya Napangga as the full manager of Lake Napangga tourist destinations has provided opportunities for people who want to be involved to play an active role and contribute to managed tourism business units, such as admission ticket officers, facilities and infrastructure rental officers, photo officers at the spot. -spots that have been provided and so on.

However, efforts to develop physical facilities and infrastructure that have been carried out have not been able to significantly increase the number of tourist visits in the Lake Napangga tourist destination. Because tourist visits generally only occur on certain big days, so that on other days there are no high tourist visits. This condition indicates that tourist visits are still seasonal. Therefore, the BUMDes Cahaya Napangga is trying to collaborate with the Regional Government of Rokan Hilir Regency and the Regional Government of Riau Province, in order to develop Lake Napangga tourist destinations from the non-physical sector. Collaboration carried out by compiling creative ideas, in order to further promote the Lake Napangga tourist destination to the general public. The real form of this collaboration is manifested through the Lake Napangga Festival activities which are included in the tourism agenda in Riau Province and Rokan Hilir Regency every year, which is precisely in October.

The Festival of Enchantment of Lake Napangga, which was referred to by the Regional Government and the managers of the Cahaya Napangga BUMDes, provides themes and concepts of local wisdom. This means that the activities carried out at this festival are based on activities that are already popular in the Tanjung Medan Kepenghuluan community, such as canoe rowing competitions on the lake, canoe decoration competitions, Malay song competitions and so on. These breakthroughs are expected to contribute to the increase in the number of tourist visits on Lake Napangga. The success of the management of BUMDes Cahaya Napangga in collaborating with the Regional Government is none other than to increase the number of tourist visits which have an unwitting effect on the economic empowerment of the community.

The tourism development carried out in Lake Napangga by BUMDes Cahaya Napangga is based on three principles of tourism development put forward by Mcinteyre (1993). The three main principles in tourism development are:

\section{Ecological sustainability}

Ecological sustainability namely ensuring that the development carried out is in accordance with biological ecological processes and the diversity of existing ecological resources. The ecological sustainability process in tourism development is carried out by protecting the entire flora and fauna ecosystems owned by these tourist destinations. This is done so that the natural nature of the ecology of the area is well preserved and maintained. Because the ecological balance that is maintained will provide benefits to every creature and plant in tourist destinations. A mutually beneficial relationship between humans and their environment will basically have a positive effect. Because successful environmental management will provide benefits or values for humans, including: economic value, mental spiritual value, scientific value and cultural value of the environment. Economic value, namely increasing income from natural products, increasing foreign exchange, expanding employment opportunities, and others. Spiritual mental values, namely the environment can add aesthetic sense, a sense of greatness and get closer to God Almighty. Scientific Value, namely the 
environment can be used as the object of research, science development, plant cultivation and ecological research. Cultural value, namely that a unique environment will give its citizens pride. science development, plant cultivation and ecological research. Cultural value, namely that a unique environment will give its citizens pride. science development, plant cultivation and ecological research. Cultural value, namely that a unique environment will give its citizens pride (Anugrah \& Sudarmayasa, 2017).

Tourism development carried out by BUMDes Cahaya Napangga for Lake Napangga tourist destinations basically follows a development pattern based on environment or ecological sustainability. This is in line with the research results (Rusyidi,B \& Fedryansah, 2018) states that tourism development must be based on a sustainable approach because it must consider environmental sustainability aspects for future interests so that it will have an impact on economic development.

This fact can be seen from several explanations by the informants that have been determined in this research, generally giving a response that tourism development in Lake Napangga should not damage the ecosystem and environmental ecology around the tourist destination area. Efforts made by BUMDes Cahaya Napangga in maintaining and preserving the environment in the tourist destination of Lake Napangga, for example, by not destroying trees and polluting lake water with visitors' trash. For more details, it can be seen in the following figure 1.

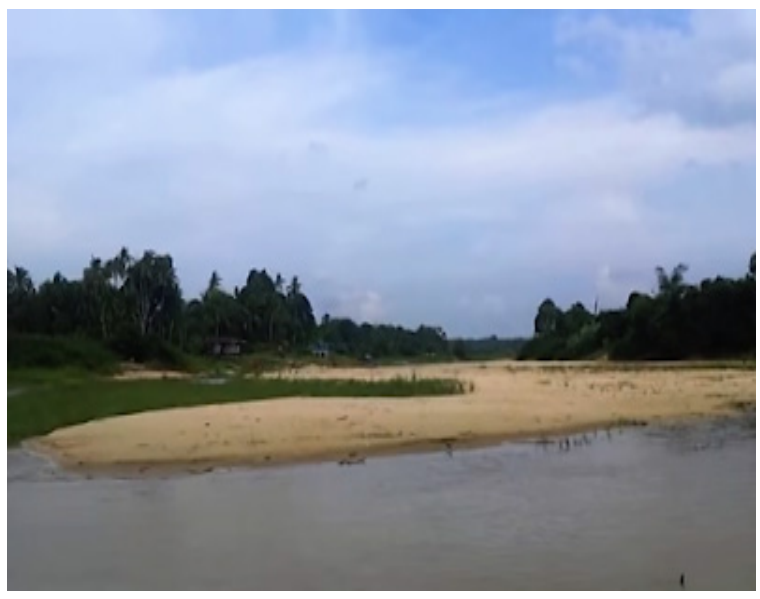

Source: Observation Data, 2020

Figure 1. Environmental or Ecological Conditions in Lake Napangga Tourist Destinations

The picture above shows that the BUMDes Cahaya Napangga as the manager of the Napangga Lake destination still maintains and preserves the nature, environment and ecology around the area. The BUMDes Cahaya Napangga really maintains and maintains the naturalness of Lake Napangga, such as there are still many shady trees, clean and clear lake water and pleasant green scenery. In an effort to preserve the ecology and environment in Lake Napangga, BUMDes Cahaya Napangga has installed many warning boards that prohibit any visitors from damaging the existing environment. Apart from that, BUMDes Cahaya Napangga also provides garbage dumps for visitors to maintain cleanliness around Lake Napangga. So far, the management of BUMDes Cahaya Napangga has tried to maintain the ecological balance in the Lake Napangga area, by disseminating information to visitors not to litter and pollute the lake water. This is done to preserve the environment and ecology as well as the beauty of Lake Napangga which is one of the mainstay destinations for the community.

\section{Social and cultural sustainability}

Social and cultural sustainability namely ensuring that the development carried out has a positive impact on the lives of the surrounding community and is in accordance with the culture and values that apply to the community. Tourism development that is carried out can stimulate the improvement of social relations in people's lives by increasing cooperation, participation and friendship among the community. In addition to increasing social relations, the cultural values that exist in the community are also increasingly developing by preserving the existing culture and the growth of local wisdom that can be promoted.

Lake Napangga tourism development carried out by BUMDes Cahaya Napangga, also pays great attention to the value of social and cultural sustainability (social and cultural sustainability). This fact can be seen from several responses from informants that have been determined, generally giving responses that the tourism development carried out in the Lake Napangga destination further strengthens the social and cultural values that exist in the community environment. The proof is that with the management of the Napangga Lake destination, many people are involved by BUMDes Cahaya Napangga, both as tourist charm officers who are members of BUMDes Cahaya Napangga or as people who participate as culinary traders and souvenir traders. This community participation and involvement shows that the social relationships that develop in the community are very good, so that good friendship can be created and a high sense of care can be created. In addition to developing social values, cultural values have also developed with the management of this Lake Napangga destination. The cultural values that have developed include the culture of maintaining the environment by not destroying the existing trees and the cultural value of art which is always displayed at the Enchantment Festival of Lake Napangga or other big days. For more details, see the following image: The cultural values that have developed include the culture of maintaining the environment by not destroying the existing trees and the cultural value of art which is always displayed at the Enchantment Festival of Lake Napangga or other big days. For more details, see the following image: The cultural values that have developed include the culture of maintaining the environment by not destroying 
the existing trees and the cultural value of art which is always displayed at the Enchantment Festival of Lake Napangga or other big days. For more details, see the following Figure 2.

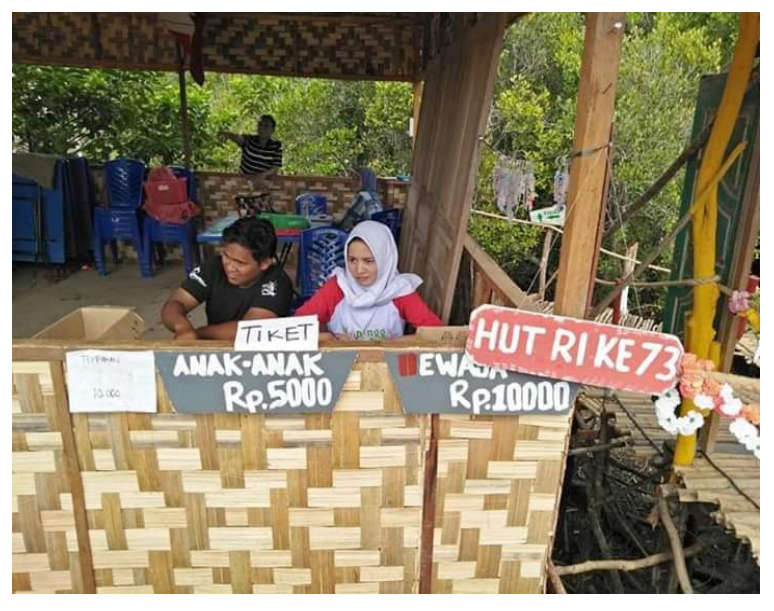

Source: Observation Data, 2020

Figure 2. Community Participation in Lake Napangga Tourism Destinations

The picture above shows that the participation and involvement of the community in activities carried out at the Lake Napangga destination is very large, this can be seen from the participation of the community in performances held at Lake Napangga. The activeness of the community in this activity proves that the social relations that have developed between the community have run smoothly, so that communication in the management of Lake Napangga together can run well. In addition, in every performance activity carried out at Lake Napangga it also increases the cultural elements that exist in the community by including community games in these activities. Community games, which are part of the agenda for performance activities, have unwittingly developed the local wisdom of the existing community. Local wisdom that is also being developed in the Napangga Lake Tourism Destination is a rowing competition. This competition is held during the Lake Napangga Enchantment Festival every October. Participants in the competition were followed by people around Lake Napangga, namely Kepenghuluan Tanjung Medan and other Kepenghuluan (villages). The development of the canoe rowing competition is carried out to maintain and preserve the culture of the people in Rokan Hilir Regency in general who used to live as river fishermen.

\section{Economic sustainability}

Economic sustainability namely the development process must be economically feasible, carried out efficiently to be able to provide significant economic benefits both for regional development and the improvement of the welfare of local communities Tourism development carried out provides economic value for managers and communities in tourist destinations. So that the development carried out is able to stimulate the economy of the people around tourist destinations. Economic revival is shown by the development of tourism that can empower the economy of the people around tourist destinations.

The tourism development carried out by BUMDes Cahaya Napangga in the tourist destination of Lake Napangga basically carries out economic sustainability. Because this development will open opportunities for the community to be actively involved in the management or supporting the economy that is managed in the Lake Napangga destination. This fact can be seen from the responses of informants who have been determined, generally giving responses that the development of tourism in Lake Napangga does have an economic effect on the community, but not maximally. This is because the number of visits that occur in Lake Napangga is still seasonal and non-continuous every day. This reality shows that the economic activities carried out by the community are also seasonal and unsustainable. Even though the community has been involved as tourist charm officers, culinary traders and souvenir traders. This condition causes the community's economic involvement in Lake Napangga tourism development activities to not fully empower the community's economy. Due to the seasonal nature of visits, the community cannot fully become a business that is managed as a new source of income for the community.

Meanwhile, according to (Saepudin, 2018) empowerment and increase community participation in taking advantage of each program must have easy access for people who want to develop their business.

This fact requires collaboration from all parties to be able to promote Lake Napangga tourism to the wider community, so that the nature of community visits is consistent and sustainable. Because with the tourism promotion being carried out, it will increasingly introduce Lake Napangga tourist destinations to the public and provide an attraction to be visited and enjoyed. If this can be done, the economic activities carried out through the development of the Napangga Lake destination can empower the community's economy and can become a new economic source that the community relies on.

According to (Sidiq, 2020) Economic sustainability in the empowerment process requires accurate strategies in developing a destination, the involvement of community leaders, housewives and village officials is the first step to create a sustainable economic ecosystem.

\section{CONCLUSION}

Tourism development is one of the efforts that need to be made by the manager of a tourist attraction in order to increase the attractiveness of a tourist attraction, the Lake Napangga tourist attraction managed through BUMDes Cahaya Napangga is slowly starting to successfully empower the community's economy, although it is still seasonal. The efforts to develop the Napangga Lake 
tourism destination, which have been carried out during the last three years, have actually opened up opportunities for people involved in managing it to have new economic sources. In addition, many facilities have been built to further add to the attractiveness of the Lake Napangga tourist destination.

\section{REFERENCES}

Ali, I.I., Sutarna, I.T., Abdullah, I., Kamaluddin, K. \& Mas'ad, M. (2019). Faktor Penghambat Dan Pendukung Badan Usaha Milik Desa Pada Kawasan Pertambangan Emas Di Sumbawa Barat. Sosiohumaniora, 21, (3), 349-354. https:// doi.org/10.24198/sosiohumaniora.v21i3.23464

Anugrah, K., \& Sudarmayasa, I. W. (2017). Pembangunan Pariwisata Daerah Melalui Pengembangan Sumber Daya Manusia Di Gorontalo. Jurnal Master Pariwisata (JUMPA), 4, 33-46. https:/doi. org/10.24843/jumpa.2017.v04.102.p03

Afrizal. (2016). Qualitative Research Methods., Jakarta: Raja Grafindo Persada.

Buttler, R. (2019). Alternative Tourism: The Thin Edge of the Wedge, in Smith and Eadington (1992) Tourism Alternative Potentials and Problems in The Development of Tourism. University of Pensylavina, Phikadelpiha.

Creswell, J.W., \& Clark, V.L.P. (2017). Designing and conducting mixed methods research. Sage publications.

Fendelli, C. (2002). Natural Tourism Planning, Faculty of Forestry Gajah Mada. Yogyakarta: Student Library.

Jaelani, A.K. (2018). Pengembangan Destinasi Pariwisata Halal Pada Era Otonomi Luas di Provinsi Nusa Tenggara Barat. Jurnal Pariwisata, 5, (1), 56-67. https://doi.org/10.31311/par.v5i1.3277

Hidayat, M. (2011). Strategi Perencanaan Dan Pengembangan Objek Wisata (Studi Kasus Pantai Pangandaran Kabupaten Ciamis Jawa Barat) Tourism and Hospitality Essentials (THE) Journal, 1, (1), 33-43.

Mcinteyre, G. Hetherington, A. Inskeep, E. (1993). Sustainable tourism development, guide for local planers, word tourism organization. Madrid, ES: World Tourism Organization
Riyanto. (2016). Analysis of Regional Tourism Development Strategy (Case Study of Dinak Culture and Tourism in Nganjunk Regency). Public Administration Journal (JAP), 1, (4), 135143.

Kushartono, E.W. (2016). Pengembangan Desa Mandiri Melalui Pengelolaan Badan Usaha Milik Desa ( BUMDes) Fitrie Arianti Universitas Diponegoro Semarang. Dinamika Ekonomi Dan Bisnis, 13, (1), 67-81.

Prasetya, D. \& Rani, M. (2014). Pengembangan Potensi Pariwisata Kabupaten Sumenep, Madura, Jawa Timur (Studi Kasus: Pantai Lombang). Jurnal Politik Muda, 3, (3), 412-421.

Rusyidi, B \& Fedryansah, M. (2018). Pengembangan Pariwisata Berbasis Masyarakat. Focus: Jurnal Pekerjaan Sosial, 1, (3), 155-165. https://doi. org/10.24843/jdepar.2017.v05.i01.p26

Saepudin, E. (2018). Partisipasi Masyarakat Pada Program Desa Mandiri Pangan Di Kabupaten Bandung. Sosiohumaniora, 20, (1), 86. https://doi. org/10.24198/sosiohumaniora.v20i1.9895

Situmorang, R. (2001) Planning and Development of Eco-Friendly Coastal Tourism, national tourism development, 6, (1) . 77-84.

Sidiq, R.S.S. (2020). Model Pemberdayaan Komunitas Adat Terpencil Dalam Mengentaskan Kemiskinan Di Kabupaten Kepulauan Meranti. Reformasi, 10, (2), 217-227.

Sidiq, S.S., Sulistyani, A.M. (2007). Strategi Promosi Ekowisata Mangrove. Jurnal Aplikasi Bisnis, 8, (1), 91-96.

Sidiq, S.S. \& Achmad, R.W. (2020). Gender aspects in remote indigenous community empowerment program in Indonesia. Jour of Adv Research in Dynamical \& Control Systems, 12, (06), 21042109.

Sidiq, R. S. S. (2020). Strategy Coastal Community Panglima Raja Village In Sustainability Of Life. Sosiohumaniora, 22, (3), 281-288.

Sidiq, R. S. S. (2020). Analisis SWOT Dalam Persiapan Pemberdayaan Sosial Komunitas Adat Terpencil. Jurnal Ilmiah Ilmu Sosial, 6, (2), 119-126. 